\title{
POLÍTICAS DA ESCRITA E CRÍTICA DO PROGRESSO NAS OBRAS DE WALTER BENJAMIN, THEODOR W. ADORNO E MAX HORKHEIMER
}

\author{
Rodrigo Rocha Resende de Oliveira ${ }^{1}$
}

\begin{abstract}
Resumo
Neste texto procuramos restabelecer o que observamos enquanto comunidade estética nos pensamentos de Walter Benjamin, Theodor W. Adorno e Max Horkheimer, vinculado também à política da escrita que exercem. Neste sentido, enxergamos duas fontes para o problema desta aproximação: a crítica à modernidade iluminista e, ao mesmo tempo, de um estilo filosófico literário adequado. Um estilo que busca na sua própria forma de apresentação confrontar a lógica dos ideais de progresso modernos. Em especial, acessamos o primeiro capítulo da Dialética do esclarecimento, "O conceito de esclarecimento"(1947), escrito a quatro mãos por Adorno e Horkheimer, para darmos maior concretude ao conceito crítico do progresso. Após este primeiro passo, outros textos de Adorno serão cotejados a fim de nos ajudar a pensar a relação entre arte e sociedade situadas no campo estético, dentre os quais estão Ideia de História Natural (1932) e as Aulas de Estética (1957/58). Por fim, alinhamos toda discussão à fortuna da concepção de apresentação que Benjamin utiliza no último texto de sua obra, as "Teses", e que traduz, novamente concatenado às noções de forma e conteúdo, uma política da escrita resistente aos módulos logocêntricos imperativos no pensamento tradicional.
\end{abstract}

\section{Palavras-chave}

Estética. História. Ideologia do Progresso. Políticas de escrita.

\section{Introdução}

No plano ampliado das teses Sobre o conceito de História, texto que Walter Benjamin escreve em 1940, a crítica acentuada ao problema do positivismo sob a ideologia do progresso é fixada justamente para demarcar uma visão apropriada e revisada por toda uma geração de pensadores. Em carta ao amigo Theodor W. Adorno, datada de 22 de fevereiro dos anos de 1940, Benjamin menciona muito claramente seu objetivo com a escrita do documento: "Estabelecer uma cisão inevitável entre nossa forma de ver e as sobrevivências do positivismo." (LÖWY, 2005, p. 33). Uma "forma de ver" que também viria a ser incorporada especialmente no primeiro capítulo de Dialética do Esclarecimento, texto que Adorno escreve em parceria com Max Horkheimer e publica alguns anos mais tarde, já em 1947. Ou seja, àquela tendência e

\footnotetext{
${ }^{1}$ Graduado em Filosofia pela Universidade Federal de Juiz de Fora (2018), é mestrando em Filosofia pela Universidade Federal de Ouro Preto, vinculado à Linha de Pesquisa em Estética e Filosofia da Arte com apesquisa intitulada "Alegoria e Redenção: das esferas política e estética nas teses Sobre o conceito de história, de W. Benjamin.”
} 
perspectiva próprias, a que Benjamin se referia na correspondência mencionada, Adorno e Horkheimer poderiam responder com o desenvolvimento de $O$ conceito de esclarecimento, capítulo que abre o projeto de desconstrução das bases iluministas.

Desse modo, se no texto sibilino de Benjamin, seu modo de recepcionar a ideologia do progresso perpassa uma ambientação histórica dirigida a intelectuais seus contemporâneos, Adorno e Horkheimer estendem o problema aos primórdios da cultura ocidental. Logo, em "O conceito de esclarecimento", os autores resgatam, através de uma espécie de método arqueológico, as ruínas mais remotas que o catastrófico percurso da razão esculpiu no afã pela dominação da natureza. Afins ao intuito histórico crítico com espírito benjaminiano, Adorno e Horkheimer retomam a origem do esclarecimento para entrever nos rituais mágicos do homem primitivo o ímpeto de "autoconservação" que os leva ao prejuízo da racionalidade positivista, com toda sua sobrecarga de abstração e afastamento do intermédio reflexivo imaginário. Ainda, Adorno e Horkheimer, atentos à crítica de Benjaminnas "Teses", enxergam que o abandono precário das fontes imaginativas que constituíram a fortuna de uma existência integral na realidade pré-moderna acontece muito por força de determinada homogeneização da realidade. Paradoxalmente, esta mesma realidade homogeneizada se mostra estilhaçada, em espectros retráteis da estratificação social moderna, o que, aliás, se torna um movimento que também aparece impresso nas formas de apresentação estritamente analíticas do pensamento.

Enquanto Benjamin (1940) revela o conceito revolucionário de leitura "a contrapelo da história" na sétima "Tese" de seu espólio Sobre o conceito de história, as implicações e potências do módulo de observação relegado por este autor reaparecem em Adorno e Horkheimer sob o mesmo prisma hermenêutico. Na medida em que, se Benjamin aponta para o erro crasso que levou os historicistas ao absurdo de congelar o passado em retratos narrativos da vitória, e busca retomar assim, ao largo dos processos históricos, a vida dos oprimidos e sujeitados pela dominação, Adorno e Horkheimer ampliam essa noção à própria tradição filosófica. Ao escreverem sobre o conceito de esclarecimento, Adorno e Horkheimer destacam o problema da orientação monolítica para o futuro previsto teleologicamente e buscam mostrar como isso acontece em virtude da lógica positivista do pensamento ocidental. E, para observação das implicações deste mesmo positivismo também no tocante ao campo das artes, recorramos então às Aulas de Estética proferidas entre os anos de 1957/58 em que 
Adorno supõe uma nuance para a noção de progresso, religada então a uma crítica da técnica.

Na quinta aula dos cursos de estética, em fala proferida na década de1950, Adorno se refere à esta problemática do ideal sobre o progresso e sua implicação no campo das artes ao escrever: "[no campo das artes] el progresso seria tan libre de una espécie de tecnocracia animal del arte como, al revés, de un oscurantismo que cree que la esencia que conserva la naturaleza del arte consistíra en definirlo en contra del progresso.”(ADORNO, 1958/59, p.171). E dito isso Adorno indica alguns nomes e referências relevantes que já haviam descartado o ideal de progresso, no sentido positivo e otimista, enquanto algo de pertinente para o caso das artes. Segundo Adorno, Hegel contrapõe a consciência comum arbitrária perante a consciência intelectiva do progresso científico, e as extirpa do núcleo autônomo que a arte sustém, enquanto Marx, por sua vez, repõe à arte de Homero, por exemplo, seu lugar de cânone no alto largo das invenções modernas (ADORNO, 1958).Dentre estes, talvez o nome menos conhecido, Jochmann, que fora leitura indicada a Adorno por Benjamin, também aparece e será ele que nos permitirá, sobretudo, pensar em uma aproximação entre o texto da quinta aula e a composição das "Teses” benjaminianas Sobre o conceito de história.

Vamos ao texto de Benjamin para relevar o que podemos sugerir enquanto intersecção dos motivos indicados até aqui e, apesar de estarmos atentos às relações internas da consecução cronológica de algumas destas referências, enfatizamos a seguinte faixa temática que aparece imbricada no liame da discussão central para nós: a crítica do progresso e a forma do discurso filosófico na sua íntima relação com a apresentação e estilo das propostas críticas. Ou seja, o que está "em jogo" é o apuramento da atividade política do teórico crítico; a política da escrita e a estética revolucionária de resistência à rarefação intelectiva do simplismo fatalista (não dialético) imbricadas numa atividade histórica alienada. O que chamamos aqui de política da escrita, enfim, que é assumida tanto por Benjamin, quanto por Adorno e Horkheimer, sob os paradigmas da não linearidade analítica agregado ao valor do ensaio, ressurge afinada à noção de que cada escolha semântica, cada incisão rítmica e elaboração imagética são partes constituintes do elemento primordial para uma nova figuração de resistência frente ao cânone da tradição filosófica. 


\section{1) A ideologia do progresso, segundo Adorno e Horkheimer}

O primeiro capítulo da Dialética do esclarecimento, "O conceito de esclarecimento" (1947) carrega na sua leitura uma gama inestimável de referências que são sublinhadas e que exigem o exercício de remissão possível aos marcos que são elencados ao longo do texto. Adorno e Horkheimer, afeitos ao valor ensaístico, constroem uma reunião de referências que articula no miolo de sua tessitura um semnúmero de entradas, de perspectivas e visões, extremamente exigentes à atividade interpretativa. Dentre sua complexa gama de referências, Max Weber aparece, certamente, ao centro da crítica dirigida à modernidade e ao progresso, motivo pelo qual buscamos apontar o prognóstico que o sociólogo alemão já havia vislumbrado em 1919 , e isso também ao descrever o espírito deste novo tempo de transformações radicais:

O destino de nossos tempos é caracterizado pela racionalização e intelectualização e, acima de tudo, pelo "desencantamento do mundo". Precisamente os valores últimos e mais sublimes retiraram-se da vida pública, seja para o reino transcendental da vida mística, seja para a fraternidade das relações humanas diretas e pessoais. (WEBER, 1982, p. 182).

Assim, a expressão "desencantamento do mundo", cunhada por Weber, está colocada numa anteposição fundamental entre imaginação e saber, e conduz o teor da crítica à rarefação de um mundo recém-chegado, moderno, à perda de sua aura. E será a partir dessa condição que Adorno e Horkheimer desvendam a transformação material que culmina em tal "desencantamento", com a chegada pretensamente incontornável de todo o aparato bélico, da própria ciência exercida em meio controlado, da imprensa e do comércio. Ainda, perfeito a este contexto, no rastro de toda dominação, diriam Adorno e Horkheimer:"[que sem]a menor consideração consigo mesmo, o esclarecimento eliminou com o cautério o último resto de sua própria autoconsciência."(ADORNO; HORKHEIMER, 1985, p. 4). Num ato de violência extremo que, além de transportar novos tempos de barbárie, se tornou o momento pungente para potencialidade de uma alienação absurda, atingindo a sensibilidade e o intelecto humanos em graus incomensuráveis de prejuízos.

Todavia, apesar de sua datação evidente, Adorno e Horkheimer procuram enfatizar que a profundeza desta dominação resguarda as origens de seu calcário num solo tanto mais árido e bem mais remoto do que este no qual viria se assentar a modernidade. Adorno e Horkheimer(1947) interpõem a este cenário cáustico a história da tradição filosófica desde os seus primórdios, desde as soleiras de Platão e seus 
seguidores, no desenvolvimento de um pensamento em que o ápice da dominação racional da natureza é maculado pelo esforço do intermédio conceitual. Escrevem Adorno e Horkheimer: "Com as Ideias de Platão, finalmente, também os deuses patriarcais do Olimpo foram capturados pelo logos filosófico." (ADORNO; HORKHEIMER, 1985, p. 5).E no limite, segundo a releitura, Aristóteles e Platão, o cânone e seus mais ilustres personagens, foram revisados pelo esclarecimento, no sentido de que "a pretensão dos universais" não passaria da mais refinada "superstição", apreendida no âmago de sua filosofia metafísica.(ADORNO; HORKHEIMER, 1985). Por um caminho retilíneo que indica o distanciamento do mito ao logos e serve igualmente aos leitores às avessas, Adorno e Horkheimer (1947)vêm descrever o percurso da racionalidade instrumentalizada em direção ao domínio finalista da natureza. Sobretudo, os autores mostram como no estágio do esclarecimento a mesma dominação viria a ser o insumo para adoção do cálculo e controle das partes e diferenças, absorvidas então numa identidade forjada ideologicamente que compreende o mesmo sobre o mesmo, em movimentos circulares e estabilizados, voltados invariavelmente para uma única direção que aponta para o cerne de si mesma.

Será neste espaço onde a intervenção de qualquer natureza oposta ao seu núcleo mais duro, excluída sob o estigma da estranheza e da figura "naturalizante" sempre afeita a uma razão ensimesmada, que o esclarecimento se arvora e mostra sua interface mais precária. Como dizem Adorno e Horkheimer: "Cada resistência espiritual que ele [o esclarecimento] encontra serve apenas para aumentar sua força." (ADORNO; HORKHEIMER, 1985, p. 6).Acima de tudo, o esclarecimento o faz por meio de uma operação que ao largo da tradição ocidental se espraiou vertiginosamente, também dado por seu modus operandi de fixação das figuras, que sempre universaliza particularidades, até os recantos de toda filosofia ocidental. E sobre os melindres do método que este processo de esclarecimento fomenta, Adorno e Horkheimer escrevem: "A multiplicidade das figuras se reduz à posição e à ordem, a história ao fato, as coisas à matéria" (ADORNO; HORKHEIMER, 1985, p. 6). O que, em última instância, implicará na concepção das narrativas desde sua forma e elaboração, ao ser imposto ao trabalho do pensamento uma exatidão que esteja incisivamente afastada de qualquer abertura considerada demasiado literária e, ou, até mesmo, poética² ${ }^{2}$

\footnotetext{
${ }^{2}$ Quando nos referimos à poética estamos pensando em algo próximo ao conceito de "poetificado" que Benjamin desenvolve no texto intitulado "A tarefa do tradutor" quando descreve algo que escaparia à atividade de tradução no caso do texto poético: "O que diz uma obra poética? O que comunica? Muito
} 
Por isso nos interessa destacar que na própria gesticulação da escritura que ensaiam Adorno e Horkheimer (1947), desde o capítulo sobre o "Conceito de esclarecimento", podemos sublinhar uma imersão num liame radicalmente oposto à dominação ideológica de ordem positivista. Por uma textura filosófica na qual está depositado o intuito de sua crítica, diretamente voltada para uma correspondência estética que desfaz o ideal positivo de dominação monolítica da razão a partir do método desviante de sua práxis literária. Ou seja, um texto que nos conduz a uma via escapatória estendida ao largo das amarras conceituais "logicistas", constelada na sua apresentação, ao procurar fazer jus ao seu discurso mais genuíno de não petrificação das formas, aliando-se finalmente a consequências ensaísticas do método desviante que ativa. $^{3}$

\section{2) O princípio linguístico da dominação, em "O conceito de Esclarecimento"}

Adorno e Horkheimer, no capítulo "O conceito de Esclarecimento", inspecionam a relação do universo mitológico e pré-filosófico, a despeito do princípio da dominação da natureza. Deste modo, os autores verificam que: "Na magia existe uma 'substitutividade' específica. O que acontece à lança do inimigo, à sua cabeleira, a seu nome, afeta ao mesmo tempo à pessoa.” (ADORNO; HORKHEIMER, 1985, p. 7).Sua atitude primitiva, que age articulada ao teor de uma "substancialidade interna", já se mostra, no momento do rito, enquanto intuito para o aprisionamento do outro; em suma, da diferença. Gerado um efeito que, na designação posterior de um exemplar neutro para realização dos ritos ,se transmuta na qualidade do sacrificado diante ao sacrifício, entregue a redução dos objetos a uma nulidade absoluta. Além do mais, o problema central para nós é que, no processo de desaparecimento destas qualidades, o espaço da lógica discursiva traduz o emprego desta mesma neutralidade iminente, qual a pretensão

pouco para quem a compreende. [//] Mas aquilo que está numa obra literária, para além do que é comunicado - e mesmo o mau tradutor admite que isso é o essencial - não será aquilo que se reconhece em geral como o inapreensível, o misterioso, o 'poético'?” (BENJAMIN, 2013, p.102). Neste sentido, enxergamos os textos que comentamos no artigo como bons exemplos de paradoxos em torno da comunicação filosófica dos conteúdos e a expressividade poética.

3 Aqui estamos nos referindo à passagem do Prefácio Epistemológico Crítico para o texto de o Drama Trágico Alemão em que lemos o seguinte - isso após falar da possibilidade que a forma do tratado filosófico tem para superar os imperativos de uma razão matemático mecânica: "Método é caminho não direto. A representação como caminho não direto: é esse o caráter metodológico do tratado. A sua primeira característica é a renúncia ao caminho ininterrupto da intenção. $O$ pensamento volta continuamente ao princípio, regressa com minúcia à própria coisa. Este infatigável movimento de respiração é o modo de ser específico da contemplação." (BENJAMIN, 2013, p. 16) Ou seja, um método do desvio que foge tanto à interpretação intencional quanto procura afastar-se de uma analítica cerrada em preceitos geômetras. 
científica acolheu também em outros espaços da vida social e cultural sua imparcialidade.

Segundo Adorno e Horkheimer: "A substituição no sacrifício assinala um novo passo em direção à lógica discursiva [...] eles já representavam o gênero e exibiam a indiferença do exemplar.” (ADORNO; HORKHEIMER, 1985, p. 7).Enfim, a ciência fomenta um método voltado para o exemplar neutralizado e instalado no ambiente laboratorial de maneira limitadora sob os moldes que reconhecemos desde a modernidade. Sua ferramenta metodológica passa a ser o referencial para objetividade no horizonte das demais formas de manifestação do espírito humano. E deste modo, apreendido racionalmente, um objeto dominado por esta razão, não suporta mais qualquer diferenciação. Os objetos se tornam anômalos, alienados de suas riquezas particulares. Ao contaminar os fundamentos da própria linguagem, a forma lógica se alastra aos campos do saber de maneira expansiva, avidamente defendido em detrimento do pensamento não abstrato em suas várias possibilidades de improvisação infinitas.

Como nas palavras de Adorno e Horkheimer: "O mundo da magia ainda continha distinções, cujos vestígios desapareceram até mesmo da forma linguística" (ADORNO; HORKHEIMER, 1985, 7). Isto é, na própria relação entre sujeito e objeto, determinado recalque da fórmula científica encerra um primeiro agente doador de sentido e o segundo "portador ocasional do significado"; estratificados por uma redoma fortuita de identidade absoluta imprimida na linguagem que assumem.(ADORNO; HORKHEIMER, 1985).O esclarecimento reelabora assim um discurso pautado pela deflação inevitável dos opostos que escapam a uma interpretação dialética da história e ditam a unidade entre as partes de cada fenômeno e contexto que apreende. Seu ápice acrítico redunda em uma contaminação que chega aos recantos de toda esfera social, como dissemos, e inclusive na filosofia, quando em seu módulo logocêntrico de produção dos sentidos parece desejar um domínio sobre seu objeto que aparece como devedor da própria metodologia científica e analítica que o sustém. Seguindo este movimento vejamos o que escrevem Adorno e Horkheimer sobre a dominação da natureza vinculada então às formas linguísticas:

[...] a totalidade desenvolvida linguisticamente, que desvaloriza, com sua pretensão de verdade, a crença mítica mais antiga: a religião popular, o mito patriarcal solar é ele próprio esclarecimento, com o qual o esclarecimento filosófico pode-se medir no mesmo plano. A própria mitologia desfecha o processo sem fim do esclarecimento, no qual toda concepção teórica determinada acaba fatalmente por sucumbir uma crítica arrasadora, à crítica de ser apenas uma crença, 
até que os próprios conceitos de espírito, de verdade, e até mesmo de esclarecimento tenham se convertido em magia animista (ADORNO; HORKHEIMER, 1985, p.7).

Finalmente, também a filosofia "sucumbe" ao mesmo "círculo mágico" que retoma ininterruptamente seu início, num movimento incessante de retroalimentação da mais "nobre das causas", a tão desejada por boa parte dos filósofos, a verdade absoluta. Como Friedrich Nietzsche anuncia sarcasticamente em $O$ crepúsculo dos ídolosreferência última tanto para Adorno e Horkheimer, quanto para Benjamin: "Razão = virtude = felicidade: isto quer dizer: é preciso imitar Sócrates e opor aos apetites sombrios uma luz do dia permanente, uma claridade que é a luz da razão". (NIETZSCHE, 2017,p. 19). E, neste sentido, o plano conceitual é submetido ao monólito da dominação tendo a obsessão pela universalidade abstrata como sustentação das bases epistêmicas no conjunto das esferas socioculturais ${ }^{4}$.Além disso, sua tendência leva ao cabo a massificação das diferenças, claro, porque, engendra, no âmago do seu espectro, uma repulsa por qualquer caractere alienado aos cálculos a que pretende conformar o devir revoltoso da história.

\section{3)Sobre o ideal do progresso no campo da arte: interstício adorno benjaminiano}

\footnotetext{
${ }^{4}$ Neste ponto, podemos citar o positivismo, sua gama de leis naturalizantes impostas à natureza mortificada, como uma das vertentes mais representativas deste movimento de clausura do exercício filosófico. Adorno e Horkheimer também sugerem o princípio de sua decisão "antipositivista" nas entrelinhas de "O conceito do esclarecimento": "[...] quanto mais se desvanece a ilusão mágica, tanto mais inexoravelmente a repetição, sob o título da submissão à lei, prende o homem naquele ciclo que objectualizado sob a forma de lei natural, [o que] parecia garanti-lo como um sujeito livre." (ADORNO; HORKHEIMER, 1985, p. 8). Fixado um quadro em que a ciência e a filosofia coadunam ao momento central do esclarecimento e à legalidade de uma suposta indiferença alcançada pelo procedimento da lógica legalista. Seja para redução última dos objetos todos, seja na apuração mínima dos fatos, quando é a história que se torna seu modelo discursivo. O sociólogo Michael Löwy caracteriza a ideologia positivista no contexto da modernidade com as seguintes palavras: "[...] o cientista social deve estudar a sociedade com o mesmo espírito objetivo, neutro, livre de juízo de valor, livre de quaisquer ideologias ou visões de mundo, exatamente da mesma maneira que o físico, o químico, o astrônomo etc." (LÖWY, 2010, p.39). Movimento que, para Adorno e Horkheimer, induz a um processo que engendra a temporalidade fatual e igualmente mortificadora, provinda das raízes míticas da cultura ocidental. Adorno e Horkheimer, ainda perante o positivismo, se colocam a partir da crítica na crença do objeto factual que, como vimos esta vertente projeta no insumo de seu plano mais profundo. Ou seja: "No mito tudo que acontece deve expiar uma pena pelo fato de ter acontecido. E assim continua no esclarecimento: o fato torna-se nulo, mal acabou de acontecer." (ADORNO; HORKHEIMER, 1985, p. 8). Afinal, a efemeridade do fato encerra outro traço comum tanto ao mito quanto ao esclarecimento, e, por conseguinte, demonstra a fragilidade dessa visão enquanto impossibilidade de haver qualquer acontecimento na sua concretude. Sobremaneira, a problemática acerca da temporalidade, que é assaltada pelo afã positivista de dominação da natureza, torna o aspecto de toda espontaneidade restringida a certa falseabilidade legitima dos termos objetivos. Altura na qual podemos reaver a noção de repetição, em que a mimese é subtraída ao sempre mesmo, ou, como nas palavras de Adorno e Horkheimer: "O princípio da imanência, a explicação de todo acontecimento como repetição, que o esclarecimento defende contra a imaginação mítica, é o princípio de todo mito." (ibid.).
} 
Devemos constatar que Adorno não descarta toda e qualquer noção que seja "afirmativa" sobre o progresso para o caso das artes; muito pelo contrário. O autor nos dirige o olhar para a particularidade desta noção dentro do campo circunscrito. Qual seja — nas palavras de Adorno: "existe un progreso del arte, por cierto, solo en un sentido totalmente determinado, es decir, precisamente en el sentido del progreso del domínio de la naturaleza" (ADORNO, 1958/59, p. 170). Domínio que ressurge conectado à noção de técnica e que carrega no seu escopo irreversíveis aquisições históricas, que servem à transformação estética dos materiais predispostos e sujeitados, e que contém, no seu fim, o que poderíamos considerar como um repertório. Todavia, torna-se necessário supor o limite histórico que a técnica comporta, seja na sua operação por esforço do artista, seja na sua ligação com a totalidade do alcance expressivo encontrado nas obras. Ao discorrer sobre isso, é curioso notar que Adorno lança mão do exemplo de uma hipotética composição artística retrógrada, justamente para estabelecer a interação entre a técnica, a expressão e o próprio decurso histórico. Assim escreve Adorno: "Por ejemplo, quien hoy quisiera intentar componer con los medios de Beethoven o pintar aún con los medios de Monet, no crearía obras con la dignidad de las de Beethoven o de las de Monet, sino mamarrachos de conservatorio o pinturas figurativas de hotel." (ADORNO, 1958/59, p. 170).

Deste modo, Adorno nos interpela com a descrição de uma dinâmica intrínseca entre a utilização e o domínio material, no espaço em que o "teor de verdade" da obra aparece vinculado à possibilidade da aquisição de uma técnica absoluta. Ou, em outros termos, a uma obra de arte que não se adequa à utilização a-histórica dos meios disponíveis para sua produção, na mesma medida em que não se reduz seu estatuto de legitimidade ao puro e mero tecnicismo. Sobretudo, o conceito de técnica para a crítica de arte adorniana significa um caractere marcante da própria humanidade. A partir do domínio da natureza, o artista, ao recorrer à técnica de que dispõe, e que sobrevém para dar forma ao material que utiliza, age segundo sua condição racional. Esta peculiaridade, que somente à cultura humana condiz, Adorno a conceitua em termos de intencionalidade ${ }^{5}$, como vemos na passagem seguinte: "No existe ningún arte al que se

\footnotetext{
${ }^{5}$ É válido anotar que a concepção de intencionalidade de que Adorno lança mão nas "Aulas" não se identifica à filosofia vigente. Adorno renega o método fenomenológico no seu recurso aos dados imediatos da realidade e chama atenção de seus alunos para isto: "ustedes tomaran o que les dije como una especie de fenomenología de la relación entre arte y naturaleza [o que Adorno complementa] que si una si atiene ahora a estas definiciones que les di, sabe entonces lo que es el arte y lo que es la naturaleza (ADORNO, 1958/59, 162). Notoriamente a ênfase crítica sobrevém depositada no movimento dialético histórico que tanto a arte quanto a natureza perdem sob a visão de um método que se afasta do devir
} 
lo puede llamar seriamente arte sin un elemento técnico - esto es, sin el momento de darle forma a su material [...] a través de una técnica e refundirlo en una intención." (ADORNO, 1958/59, p. 167).Situado socialmente, o artista, no exercício de sua atividade artística, toma para si a intenção emancipatória de transformação da realidade.

Como auferimos nas palavras de Adorno: "el arte [...] no puede conservarse, de algún modo, estático en si mismo, sino que él tiene necesariamente que participar de esta realidad, en la medidas en que está en una interacción - y también en una relación antitética - con ella."(ADORNO, 1958/59, p. 168).A dominação da natureza, que afigura a noção de progresso no campo da arte, ressurge então consonante aos meios e aquisições da técnica além de ser retomada por um caminho de transformação material e de origem cultural. Segundo Adorno, para a arte, é primo “[...] que se mantenga fiel a su determinación en contradicción con el mundo, que admita precisamente ese carácter cultivado que verdaderamente define a su campo específico y vuelva a entablar relación con elementos de la realidad empírica." (ADORNO, 1958/59, p. 163). Mas isso não acontece na inauguração milagrosa de um refúgio ou simulacro para manutenção dos meios disponíveis que seria a cura das mazelas existenciais ou mundanas. A implicação deste invólucro entre arte e realidade não é admitida, como diria sarcasticamente Adorno, como se fosse para a reconstrução de "una especie de 'reserva natural de la cultura"” (ADORNO, 1957/58, p. 164). Por isso é que arte e sociedade estão envolvidas, ao mesmo tempo, pelo distanciamento da brutalidade que a natureza comporta através do domínio progressivo e pelo reclame contraditório à dominação de uma natureza controlada na sua expressão e espontaneidade absolutas.

\section{4) História, Natureza e Arte}

Ainda na década de 1930, em outro texto intitulado Ideia da História natural, que discorre sobre a problemática relação entre natureza e história, Adorno escreve o seguinte — com a devida licença para uma citação mais estendida:

histórico. Segundo Adorno, um método não dialético e histórico enxerga as esferas da arte e da natureza como se estivessem sempre aí, imóveis e inalteradas condicionadas a um modelo resistente inclusive à concepção técnica de que dispõe. Técnica como aquisição histórica de condições de transformação da natureza a partir da racionalidade e dos meios sensíveis sim, mas não por sob a negação da alteridade implicada.Na citação que escolhemos, fica evidente o desmonte da estabilidade que a fenomenologia pretende subtrair às circunvoluções históricas de que a arte também compartilha: “[...] esta relación entre naturaleza y arte, precisamente como si las presenté, no es algo, digamos, estático; no existe de una vez e para siempre la esfera de la naturaleza, por un lado, y la esfera del arte, por el otro, sino que estos dos momentos están constantemente, uno con respecto al otro, en una relación de tensión - y es probable que estén tanto tiempo como exista arte en general - y la relación de estos dos momentos entre sí se modifica, una y otra vez, en todos los periodos de la historia del arte.”(ADORNO, 1957/58, p. 162). 
Para a elucidação do conceito de natureza que pretendo dissolver, basta afirmar que se trata de um conceito que, caso eu quisesse traduzi-lo na linguagem conceitual filosófica usual, poderia ser traduzido preferencialmente pelo de mítico. Esse conceito [//] também é totalmente vago e sua determinação exata não pode ser dada em definições prévias, mas somente por meio da análise. Ele significa o que existe desde sempre, o que sustenta a história humana como um ser imposto de forma predestinada e preexistente, manifestando-se nela como o que lhe é substancial. O que se delimita com essas expressões é o que entendo aqui por natureza. A questão que se coloca é sobre a relação dessa natureza com o que entendemos por história, de tal forma que esta significa um modo de comportamento do ser humano proveniente da tradição, caracterizado, sobretudo pelo fato de nele se manifestar algo qualitativamente novo, sendo um movimento que não se desenrola em pura identidade, em pura reprodução do que sempre já existiu, mas sim no qual ocorre algo novo e que obtém seu verdadeiro caráter através do que se manifesta nele como novo. (ADORNO, 2018, p. 458).

O traço antinômico do nexo entre natureza e história insere no panorama de sua diferenciação a dinâmica dialética de uma concepção crítica que, por sua vez, remove a estabilidade metafísica, ou mítica, de uma natureza intocada e atemporal, e para tanto, Adorno divide os percursos da problemática em dois momentos. No primeiro deles, Adorno discorre sobre a questão desde uma crítica dirigida a perspectiva fenomenológico-ontológica para, enfim, acessar aos trabalhos de Lukács e Walter Benjamin, que fazem frente àquela corrente fenomenológica. Atentos ao segundo momento deste plano adorniano, podemos compreender a princípio que Lukács interpreta o mundo dividido também por dois substratos: o mundo imediato e o mundo alienado. No mundo alienado descrito por Lukács o sujeito estranha os produtos de sua própria natureza, ou seja, é alienado frente ao material produzido por sua própria ação humana. E como explicita Adorno, neste motivo lukacsiano, as coisas do mundo, uma vez que não reconhecidas, se tornam mera convenção. Nas palavras exatas da descrição que Adorno elabora, enfim: "[trata-se de] um mundo cuja onipotência somente se esquiva o mais profundo da alma [...] mas que, em toda essa conformidade a leis, não se oferece, seja como sentido para o sujeito que busca um objetivo, seja na imediatidade sensível para o sujeito que age.” (ADORNO, 1932, p. 470).

Seu isolamento perante a natureza "morta e coisificada" se torna o próprio modo do espanto (taumázein) que o acomete ao ingressar neste mundo em que vive e trabalha alienado de si mesmo. (ADORNO, 1932). E isso acontece no exato momento em que o sujeito antevê a possibilidade da história natural como preenchimento para o nexo entre o simbólico, o lírico e a natureza bruta, por uma extração final que comporta 
determinada passagem da primeira natureza para uma segunda natureza. Num espaço em que permanece latente ainda o despertar para a história natural e o invólucro da forma originária da "ressurreição teológica, em horizonte escatológico" se pensarmos com Lukács. (ADORNO, 1932, p. 472). Todavia, segundo Adorno, este último termo é superado nos estudos que Benjamin realiza a partir da doutrina alegórica. Vejamos o insumo da revisão benjaminiana nas palavras de Adorno:

Usualmente, alegoria significa apresentação sensível de um conceito, e, por isso, ela é considerada abstrata e contingente. A relação entre o que se manifesta alegoricamente e o que é significado, porém, não é uma relação sígnica contingente, pois, na verdade, está em jogo um particular, ela é expressão, e o que está em jogo em seu espaço, que se exprime, nada mais é do que uma relação histórica. O tema do alegórico é simplesmente a história. (ADORNO, 2018, p. 473).

Benjamin reaproxima o problema sobre a ressurreição da segunda natureza a uma reflexão filosófica, num movimento que soergue os objetos paralisados e cifrados, ao seu despertar redentor, como objeto da interpretação. (ADORNO, 1932).Desde a filosofia da história benjaminiana, o transiente eterno (Vergagnis) foi apreendido pelo olhar saturnal dos poetas alegóricos e resgatado no artifício da escrita para, enfim, reconhecer sua historicidade. Com este reparo realizado por Benjamin, finalmente, escreve Adorno: “a própria natureza apresenta-se como transiente, como história”, e apesar de sua contradição elementar no jogo dos significantes e os significados, a alegoria tem por objetivo expressar essa condição. (ADORNO, 1932, pp. 472-473). Assim, uma alegoria produz nada mais do que a expressão da particularidade encontrada nas manifestações das coisas, e o seu significado é reposto através do elemento carregado de historicidade que sua particularidade mesma insufla. Sobretudo, neste sentido é que Benjamin destaca a diferença da operação alegórica em comparação com outra modulação expressiva, a expressão simbólica, pautado então pela categoria do tempo que ambas as formas de escrita devem compreendem.

Sobretudo, o texto alegórico será aquele que aborda a temporalidade impregnada nas ruínas que são opacas à iluminação simbólica, clássica, que ignora simplesmente a faixa catastrófica que o progresso tem na conta de sua evolução impassível. Afinal como nas palavras de Benjamin, desde a Origem do drama trágico Alemão, sabemos que:

Está aqui o cerne da contemplação de tipo alegórico, da exposição barroca e mundana da história como via crucis do mundo; significativa ela o é apenas nas estações de sua decadência. Quanto maior a significação, maior a sujeição a morte, porque é a morte que 
cava mais profundamente a tortuosa linha de demarcação entre a physis [natureza] e a significação. (BENJAMIN, 2013, p. 177).

Por conseguinte, a noção de expressão que Adorno recolhe do procedimento alegórico nos estudos benjaminianos encerra uma passagem crucial para a definição da obra de arte ligada também à noção da história dos oprimidos. Se regressarmos ao texto da quinta aula citada anteriormente, observamos que Adorno registra a seguinte assertiva: "Creo que el momento que en el arte se nombra en general con la palabra expresión $[\ldots]$ se relaciona precisamente con el hecho de que el arte es la voz de lo oprimido, pues la expresión equivale siempre a la expresión del sufrimiento."(ADORNO, 1957-58, p. 160). Portanto, a arte, tanto para Adorno quanto para Benjamin, possibilita uma articulação entre as esferas estética e política no confronto com a heteronímia da natureza e o enfrentamento dialético do progresso por meio da expressão vária de uma alegoria; o que inclusive faz valer o partido de sua própria posição revolucionária.

\section{5) O partido da arte no decurso histórico}

A arte engendra, desde sua interface crítica, dirigida ao processo de dominação racional e iluminista da natureza, a possibilidade de liquidar o princípio de realidade. E desafiar o princípio de realidade por intermédio da arte significa, acima de tudo, reaver a supressão das capacidades miméticas que o ideal de progresso negaceia ao ser social. Nas palavras de Adorno, significa então:"hacerle justicia a todo lo que fue sacrificado a este concepto progresivo del dominio de la naturaleza." (ADORNO, 1958/59, p. 157). Reparo constituído por determinada ordem política que se alarga do rompimento com a autoconservação da mesmice e da "regressividade" mimética, aos excluídos da história, na rememoração do sofrimento e pela resistência encontrada na arte. Uma vez que está imposta na finalidade de dominação racional, a inscrição da narrativa positivista, que, maquinal e perversa, deixa para traz a recordação da integridade humana, é jus para o ato da revolução comover esta espécie de transmutação estética. Resistente frente à dominação que desde o seu desenvolvimento se esquece, em prol do progresso, da natureza no próprio sujeito e, com isso, esquece também de sua característica sentimental, o que cabe a arte recompor será esta integralidade. Mas não fortuitamente, quando sim, na plenitude afirmativa de outro mundo possível, que permanece latente. Como concebe Adorno: 
[...] el arte nos promete por su mera existencia: dispensarnos, de la omnipotencia de, precisamente, ese principio de realidad, por lo tanto, dispensarnos de la omnipotencia del mecanismo de una autoconservación a expensas de todo aquello que, fuera della, hay en el mundo.(ADORNO, 1958/59, p. 159)

O partido da arte absorve na sua memória as perdas e ruínas que a modernidade relega como escassez das conquistas científicas e técnicas, ao entulho descartado pelo avanço retilíneo e progressivo que está voltado para o futuro em todas as projeções positivistas. Partido da arte que, como escreve Adorno:"[exerce sua política] por las víctimas; [que garante] que a historia este peinada a contrapelo, que por lo tanto, no sea historia desde el punto de vista del vencedor." (ADORNO, 1958/59, p. 159).Aliás, isto acontece num panorama fixado também pela temática que traz a "Tese" de número VII em que Benjamin anuncia a forte expressão: “a contrapelo da história.” (LÖWY, 2005, p. 70).Sobretudo, neste contexto "constelatório" de interação entre a estética da escritura e seu engajamento, como se fosse o amálgama do conteúdo e a forma, algo que esta mesma interação pressupõe, a história será o médio da reflexão que poderá produzir uma transformação revolucionária. O fio condutor que religa as esferas política e estética no exercício a que nos propusemos parte fundamentalmente do aspecto de ruptura radical com o contínuo progressista da narratividade, porque, afinal, ir ao "contrapelo da história" deve romper com o sentido único que as coordenadas do progresso indicam. Romper, na atividade de sua imaginação alegórica, com o sentido da própria expressão simbólica que tende a se tornar fortuitamente o plasma unificador de acontecimentos encadeados dentro de um modo operante sintetizador dos fenômenos. Ou, como Benjamin escreve na "Tese” de número VII, devemos destacar que:

[...] Não há um documento da cultura que não seja, ao mesmo tempo, um documento da barbárie. E assim como ele não está livre da barbárie, também não o está o processo de sua transmissão, transmissão na qual ele passou de um vencedor a outro. Por isso, o materialista histórico, na medida do possível, se afasta dessa transmissão. Ele considera como sua tarefa escovar a história a contrapelo. (LÖWY, 2005, p.70)

Porque não escovamos a história, ela não é um corpo animal em si; somos reconduzidos por meio dos saltos alegóricos às circunvoluções imagéticas que sua interpretação nos revoga. Escovar, nesse sentido, poderia ser levantar o pelo assentado, remover a caspa incrustada, e pôr à mostra a carne protegida por debaixo de um brilho falso que nos descreve um narrador espúrio que anuncia sempre boas novas. Assim como, para o caso da história, quando lida por um viés contraditório ao discurso 
vencedor, escovar poderia alardear um processo em que foram mantidos os personagens excluídos da expansão hegemônica, na rememoração de seu sofrimento e luta, como processo redentor. Acerca destes pressupostos, Jeanne Marie-Gagnebin registra um trecho que delineia a agudez da conexão entre os pensamentos de Adorno e Benjamin, de maneira que considera a doutrina alegórica como princípio para o encontro entre as perspectivas dos dois filósofos, especialmente no tocante ao que escrevem sobre certos aspectos da arte. À guisa de uma primeira aproximação, introduzimos esta seção com a seguinte passagem:

A doutrina benjaminiana da alegoria está, neste sentido, muito próxima das considerações de Hegel a respeito da arte romântica cristã, superior espiritualmente ao ideal clássico da "bela aparência do espírito na sua forma imediata [...] "sensível" [dito isto, e o que se segue, em referência direta à estética de Hegel], uma arte que abre para a negatividade e para a morte e que quer "absorver" a existência real na sua deficiência de existência finita". Não é preciso dizer que esta doutrina será absolutamente essencial para a elaboração da estética de Adorno que, já em 1932, dava um seminário sobre a Origem do Drama barroco Alemão na Universidade de Frankfurt. (GAGNEBIN, 2013, p. 36)

Quadro que soergue determinada atmosfera por via da qual consideramos em aproximação a forma de apresentação que a filosofia de Benjamin assume principalmente nas teses Sobre o conceito de história, vinculado a alguns dos escritos adornianos que versam sobre a relação entre estética e sociedade. Neste sentido, chamanos atenção o paradoxo colocado por Adorno, lançado ao jogo dialético do progresso no campo da arte: progresso interno e externo ao campo da arte. Contraste recriado para delinear uma aproximação a Benjamin, sendo o progresso ideológico do positivismo, que emprega a dominação cientificista da natureza, o tema comum entre eles; pautados pela crítica da técnica que suas margens propõem. Afinal, arte e política enquanto esferas religadas nos trabalhos de Benjamin e Adorno - e por extensão Horkheimer — segundo o princípio de que toda grande arte, como diria o primeiro certamente em consonância ao segundo, deve expressar o sofrimento dos oprimidos e apresentar outro caminho para uma concepção de técnica revolucionária, também supõem um elo transversal entre os textos que abordamos.

\section{6)Arte, Crítica da Técnica e Progresso}

Havemos um recorte mais pontual para reatar a crítica adorniana e horkheiminiana ao problema que Benjamin desenvolve amplamente nas teses Sobre o 
conceito de história, pautados pelas palavras-chave progresso e técnica. Para tanto escolhemos, dentre algumas passagens, aquelas que vão ao encontro de uma definição conceitual do progresso sempre enunciada paralelamente à questão da técnica. Observamos que Benjamin elabora esta obra a partir do deslocamento na direção da centralidade de uma crítica ao ideal de progresso encontrado no plano do historicismo e do positivismo, destaques como correntes citadas pelo autor nas mais diversas variações e roupagens que configuram. Notamos que apesar de sua presença no horizonte de cada uma das "Teses" que acessamos há de se considerar que, em algumas delas, o confronto com o conceito de progresso assume maior evidência e também o conceito de técnica aparece circunscrito por esta mesma discussão. A título de exemplo, exatamente na “Tese” de número XIII, encontramos a seguinte proposição elaborada por Benjamin:

A teoria socialdemocrata, e, mais ainda, a sua práxis estavam determinadas por um conceito de progresso que não se orientava pela realidade, mas que tinha uma pretensão dogmática. $\mathrm{O}$ progresso, tal como ele se desenhava na cabeça dos socialdemocratas, era, primeiro, um progresso da própria humanidade (e não somente das suas habilidades e conhecimento). Ele era, em segundo lugar, um progresso interminável (coincidente a uma perfectibilidade infinita da humanidade). Em terceiro lugar, ele era tido como um progresso essencialmente irresistível (como percorrendo, por moto próprio, uma trajetória reta ou em espiral). Cada um desses predicados é controverso, e cada um deles oferecia flanco à crítica. Mas essa, se ela for implacável, tem de remontar muito além de todos esses predicados e dirigir-se àquilo que lhes é comum. A representação de um progresso do gênero humano na história é inseparável da representação do avanço dessa história percorrendo um tempo homogêneo e vazio. A crítica à representação desse avanço tem de ser a base crítica da representação do progresso em geral. (LÖWY, 2005, p.116)

A representação do avanço da história sobre a condução de um tempo esvaziado tudo tem a ver com a perda do aspecto qualitativo, assim como nos foi anunciado por Adorno e Horkheimer (1947), além de, enquanto representação, aparecer como uma forma de manifestação abstrata. ${ }^{6}$ Ademais, a crença na dominação da natureza, que

\footnotetext{
${ }^{6}$ Dizemos isto tendo como referência uma diferenciação sutil que Jeanne Marie Gagnebin defende entre o conceito de apresentação (Darstellung) e o próprio conceito de representação. Gagnebin escreve: "O primeiro mal-entendido a ser dirimido é uma questão de tradução. A palavra Darstellung — utilizada por Benjamin para caracterizar a escrita filosófica — não pode, (aliás, nem deve), ser traduzida por "representação", como o faz Rouanet (que compreendeu perfeitamente o alcance do texto, conforme sua "Apresentação" muito esclarecedora demonstra, mas que o traduziu, às vezes, de maneira pouco precisa), nem o verbo darstellen pode ser traduzido por "representar". Mesmo que essa tradução possa ser legítima em outro contexto, ela induz, no texto em questão, a contrassensos, porque poderia levar à conclusão de que Benjamin se inscreve na linha da filosofia da representação - quando é exatamente desta, da filosofia da representação, no sentido clássico de representação mental de objetos exteriores ao sujeito, que Benjamin toma distância. Proponho, então, que se traduza Darstellung por "apresentação" ou
} 
perpassa em seu turno a abolição da dialética movedora dos processos históricos, segundo uma abertura para transformação emancipatória, encerra o debate interstício entre os teóricos críticos. Benjamin, por sua vez, aborda o conceito de progresso a partir de uma tomada geral com intensidades reatadas às concepções de "autoconservação" da humanidade, a despeito de um progresso de toda a humanidade, a perda da noção de individualidade, próximo da perfectibilidade absolutista e, por fim, o irresistível avanço retilíneo da história, semelhante à lógica finalista de uma temporalidade homogeneizada ${ }^{7}$.

Adorno e Horkheimer (1947), na esteira de Benjamin, instauram a crítica do esclarecimento ao rastrearem os ideais do tecnicismo como fontes para o instrumental científico e relegam, mais uma vez, uma ponte sólida entre as textualidades que viemos elencar: do primeiro capítulo da Dialética do esclarecimento às "Teses" benjaminianas. Crítica ao tecnicismo que suborna as qualidades fenomênicas da natureza em prol de um domínio laboratorial e controle das diferenças que a própria natureza emana em seu devir a ser. Tomada por uma racionalidade instrumental que será desenvolvida plenamente, então, por este ideal cientificista e, portanto, como dizem Adorno e Horkheimer: "[Esta racionalidade instrumental] Rigidamente funcionalizada, ela é tão fatal quanto à manipulação calculada com exatidão na produção material e cujos resultados para os homens escapam a todo cálculo. [Num espaço onde] Cumpriu-se afinal sua velha ambição de ser um órgão puro dos fins." (ADORNO; HORKHEIMER, 1985, p. 15).Órgão que funciona por um paradoxal regime de funcionamento localizado no auge de toda racionalização científica do positivismo e na representação da realidade por cálculos com resultados extremamente prejudiciais também para a narrativa da história.

\footnotetext{
“exposição", e darstellen por "apresentar" ou "expor", ressaltando a proximidade no campo semântico com as palavras Ausstellung (exposição de arte) ou também Darstellung, no contexto teatral (apresentação). (GAGNEBIN, 2005, p. 184). Mesmo ao longo de nosso texto, este preceito proveniente então da tradução é norteador quando falamos sobre a apresentação do texto das "Teses", por exemplo.

${ }^{7}$ Michael Löwy comenta a "Tese" de número XIII e destaca os caracteres mais fortes do progresso fixado naquilo que o torna conservador e falível ideologicamente. Desse modo, Löwy enxerga que será "preciso distinguir entre o progresso dos conhecimentos e das habilidades (Fahingkeiten) e o progresso da própria humanidade: este implica uma dimensão moral, social e política que não é redutível ao progresso científico e técnico" (LÖWY, 2005, p.116). Em seguida, Löwy acentua que "um progresso da própria humanidade' não se pode confundir em um progresso de aperfeiçoamento gradual e infinito, mas é preciso lutar por uma ruptura radical" (ibid., p.117). Por fim, Löwy defende, no lastro da "Tese" benjaminiana, que não há “progresso 'automático' ou 'contínuo'; a única continuidade é a da dominação e o automatismo da história simplesmente reproduz esta (a 'regra')" (ibid.). Enfim, toda confusão entre o progresso moral e social e o próprio progresso da própria humanidade, assomado a concepção de um tempo que segue a marcha ininterrupta para o futuro, torna-se uma constante dentre os pressupostos relevados.
} 
Outra das teses Sobre o conceito de história que nos remete ao progresso situado nesta mesma linha de conceituação é notoriamente a de número IX. Texto em que o teor alegórico do pensamento benjaminiano vem à tona com sua máxima expressividade e no qual a imagética toma o lugar revolucionário contra toda concepção de avanço "irresistível" da história; que confere primor à imagética incorporada no módulo de interrupção sobre o continuísmo a fim de resgatar a sensibilidade subtraída aos conceitos abstratos. Para tanto, Benjamin elabora a seguinte invenção — inspirado por uma obra de Paul Klee, o Angelus Novus:

Existe um quadro de Klee intitulado “Angelus Novus". Nele está representado um anjo, que parece estar pronto de afastar-se de algo em que crava seu olhar. Seus olhos estão arregalados, sua boca está aberta e suas asas estão estiradas. O anjo da história tem de parecer assim. Ele tem seu rosto voltado para o passado. Onde uma cadeia de eventos aparece diante de nós, ele enxerga uma única catástrofe, que sem cessar amontoa escombros sobre escombros e os arremessa aos seus pés. Ele bem que gostaria de demorar-se, de despertar os mortos e juntar os destroços. Mas do paraíso sopra uma tempestade que emaranhou suas em suas asas e é tão forte que o anjo não pode mais fechá-las. Essa tempestade o impele irresistivelmente para o futuro, para o qual dá as costas, enquanto o amontoado de escombros diante dele cresce até o céu. O que nós chamamos de progresso é essa tempestade. (LÖWY, 2005, p. 87)

Os artifícios da interpretação e escritura alegórica, ao aparecerem sinteticamente implicados, em diferentes níveis de exploração técnica, crítica e literária, retidos num só ato, convergem para o lugar das esferas alternativas, entre a política e a estética. Ou seja, além de interpretar o quadro de Klee de maneira alegórica, ao enxergar nesta obra algo que não esteve ali, necessariamente intencionado pelo artista plástico - ao desviar-se do sentido qualquer que o original pode trazer à sua composição - Benjamin vai além. O filósofo reinventa uma alegoria que transmuta o sentido teológico que a figura do anjo alcança, por sobre outra significação, histórica e política, que passa a ser possível no contexto das "Teses" por intermédio de sua apresentação estética. A redenção que o anjo aponta, enfim, com seu olhar vidrado, voltado para o passado, que segue na contracorrente da ventania paradisíaca, está posta enquanto devir do movimento revolucionário que requer uma leitura atenta para com toda catástrofe prenunciada nos traços plásticos da escrita. Assim, a "Tese” de número IX provoca uma ruptura com o sentido literal ao se elevar o novo motivo alegórico, ou os novos motivos que possamos exercitar juntamente à filosofia de Benjamin, do interior da obra para a externalidade histórico-política de onde se fala. 


\section{Conclusão: o legado crítico e a política da escrita benjaminiana}

$\mathrm{Na}$ filosofia benjaminiana, a política intervém na teologia, e estas duas esferas em jogo são lançadas ao meio estético, onde entrevemos a imbricação no âmbito de uma terceira esfera, a esfera social. E é por força deste complexo filosófico que Benjamin introduz-nos a um ambiente conflituoso que estremece as certezas ideológicas do positivismo e a separação forjada dos diversos meios de que a realidade provém. Como podemos observar na "Tese" de número X:

“[...] Partimos da consideração de que a crença obstinada desses políticos [ao se referir àqueles que defrontam o fascismo entre socialdemocratas e marxistas ortodoxos] no progresso, sua confiança em sua 'base de massas' e, finalmente, sua submissão servil a um aparelho incontrolável, foram três aspectos de uma única e mesma coisa." (LÖWY, 2005, p. 96)

Assim, Benjamin destaca o ímpeto eufórico que o discurso hegemônico assume no endereçamento das suas arguições para um único movimento; o movimento de declive para o futuro, inconsequente e, ao mesmo tempo pré-determinado. Seu intuito, além de redirecionar para um lugar comum toda a narrativa histórica dos vencedores, desvenda-nos o aspecto massificador subjacente, do qual também falavam Adorno e Horkheimer (1985). Lembremos que o guia ideológico da juventude hitlerista descrita por estes dois autores foi levar a grande parte dos seus adeptos ao cabo da igualdade veiculada por uma faceta controversa de sua mais perversa desigualdade. Sua promessa alienante foi deixar aos vitimados pela supremacia o esquecimento das diferenças e com a justificativa racionalizada para o exercício da repressão pautada por essa mesma supressão do altero. Além de ter como consequência de sua alienação a própria ideologia do progresso que, como viemos destacar, promoveu nada menos do que a precariedade nas próprias relações humanas dentro do corpo social mais amplo.

Portanto, reaver o passado, desta perspectiva benjaminiana sobre a história, atestada pela real possibilidade de redenção revolucionária em defesa dos sempre excluídos dos documentos oficiais de registro, reassume a diferença como valor inestimável, e o acontecimento menor como contrapeso igual de sua relevância. Contudo, a ideologia do progresso desnorteia todas as frentes modernas do pensamento, e todas elas imbuídas no aprimoramento das forças produtivas do aparelho industrial e na conformação da marcha adiante pelo progresso. Na "Tese" de número XI, Benjamin reforça: “[...] O desenvolvimento técnico parecia-lhe o declive da correnteza em cujo 
sentido acreditava nadar. Daí em um só passo até a ilusão de que o trabalho fabril, que se insere no sulco do progresso técnico, representaria um feito político.” (LÖWY, 2005, p. 100) E demonstra a cegueira deste tipo de abordagem (inculcada inclusive por vertentes marxistas produtivistas) para com aquilo que permanece excluído do processo de dominação da natureza como excesso.

Todas as vertentes fascistas veiculadas a uma percepção do trabalho que está fadada à alienação do ser humano e do âmbito social de seus esforços reais, abandonados ao otimismo técnico-científico, sustentado, paradoxalmente, pelo signo da ignorância, são alvos da nova crítica sobre a história que Benjamin inaugura. E a teoria que Benjamin sustenta, ainda na mesma "Tese" de número XI, que funciona para contrapor a esta má compreensão das linhas que Marx havia deixado ao arcabouço crítico das escolas vindouras, é pautada por uma releitura de Charles Fourier recolhido na sua máxima amplitude poética:

Segundo Fourier, o trabalho social bem organizado deveria ter por consequência que quatro luas iluminassem a noite terrestre, que o gelo se retirasse dos polos, que a água do mar não fosse mais salgada e que os animais de rapina se pusessem a serviço do homem. Tudo isso ilustra um trabalho que, longe de explorar a natureza, é capaz de dar à luz das criações que dormitam como possíveis em seu seio. (LÖWY, 2005, p. 100)

Para dizer a contracorrente da exploração dos meios de produção e do trabalho, claro, não bastaria a Benjamin ir aquém da colocação de "quatro luas" no céu de um mundo outro, nada menos do que desfazer o "gelo dos polos" ou, a harmonia junto aos "pássaros de rapina", como na citação acima. Todo seu escolho transita entrelinhas, na direção de um recorte que absorve a poética, a ilustração imaginativa daquilo que permanece por vir e que tem como invariável somente sua característica de oscilação e incógnita. Suas escolhas almejam o princípio de uma escritura que permeia toda estrutura das "Teses" naquilo que têm de busca pela resistência política frente uma noção da verdade que se representa como unilateral, de uma linguagem representativa que se manifesta como dominadora. São estes os traços gerais do legado crítico que Benjamin deixou para pensarmos o exercício da crítica sobre a modernidade e, acima de tudo, para pensarmos o médio reflexivo que deve ser o exercício da escrita politicamente situada. Se a direção que Adorno e Horkheimer (1985) tomaram pudesse ser esmiuçada a partir do recorte proposto, buscamos trazer como conclusão o arcabouço teórico do qual compartilharam desde a leitura de Benjamin que também nos instiga. 


\section{Referências}

ADORNO, Theodor W; HORKHEIMER, Max. A dialética do esclarecimento. In O conceito de esclarecimento. Trad. Guido Antônio de Almeida. Rio de Janeiro: Zahar, 1985.

ADORNO, Theodor W. Estética: 1958/59. Trad. Silvia Schwarzbock. Buenos Aires: Las Cuarenta, 2013.

Primeiros escritos filosóficos. In Ideia da história natural. Trad. Verlaine Freitas. São Paulo: Editora Unesp, 2018.

BENJAMIN, Walter. Origem do drama trágico alemão. Ed. e trad. João Barrento. $2^{\text {a }}$ Ed. Belo Horizonte: Autêntica, 2013. (Filô/Benjamin).

GAGNEBIN, Jeanne Marie. Do conceito de Darstellung em Walter Benjamin ou Verdade e Beleza. In KRITERION, Belo Horizonte, n 112, p. 183-190, dez/2005.

.História e Narração em Walter Benjamin. São Paulo: perspectiva, 2013.

LÖWY, Michael. Método dialético e teoria política. Trad. Reginaldo Di Piero. Rio de Janeiro: Paz e Terra, 1978.

Walter Benjamin: aviso de incêndio: uma leitura das teses "Sobre o conceito de história". Trad. Wanda Nogueira Brant, [tradução das teses] Jeanne Marie Gagnebin, Marcos Lutz Muller. São Paulo: Boitempo, 2005.

.Ideologias e ciência social: elementos para uma análise marxista. São Paulo: Cortez, 2010.

NIETZCHE, Friedrich. O crepúsculo dos ídolos. Ou a filosofia a golpes de martelos, Trad. Edison Bini; Marcio Pugliese. São Paulo: Nova Fronteira, 2017.

WEBER, Max. Ensaios de Sociologia. Trad. Waltensir Dutra. Rio e Janeiro: LTC, 1982.

\section{POLITICS OF WRITING AND CRITIQUE OF PROGRESS IN THE WORKS OF WALTER BENJAMIN, THEODOR W. ADORNO AND MAX HORKHEIMER}

\footnotetext{
Abstract

In this text we seek to reestablish what we find, as an aesthetic community, in the thoughts of Walter Benjamin, Theodor W. Adorno and Max Horkheimer, that is also
} 
linked to the politics of writing they employ. In this sense, we see two sources for the problem of this approach: the criticism of the enlightened modernity and, at the same time, of an adequate literary philosophical style. A style that seeks in its own form of presentation to confront the logic of modern ideals of progress. In particular, we discuss the first chapter of the Dialectic of Enlightenment, "The concept of Enlightenment" (1947), written by Adorno and Horkheimer, to give more concreteness to the very concept of progress they developed. After this first step, other texts by Adorno help us to interpose the relationship between art and society in the field of aesthetics: The Idea of Natural History (1932) and Aesthetics (1958/59). Finally, we link the discussion to the concept of presentation that Benjamin uses in the last text of his philosophical work, which translates, together again with the notions of form and content, a politics of writing impervious to the logocentric modes of traditional thinking.

\section{Keywords}

Aesthetic. History. Ideology of Progress. Politics of Writing. 